\title{
Violation of the Conversational Maxims in the Humorous Utterances in Comedy Program 'The East'
}

\author{
Angelina Kencana \\ English Department, Faculty of Letters, Petra Christian University, Siwalankerto 121-131, Surabaya \\ 60236, INDONESIA \\ E-mail: m11414040@john.petra.ac.id
}

\begin{abstract}
This study is conducted in order to reveal the violated maxims in the humorous utterances and the implicature of the maxim violations in NET comedy program 'The East', from a discourse analysis point of view. The writer analyzes the types of maxims that are violated found in the humorous utterances in episode 397 entitled 'Ribet Milih Tempat Kerja Baru' (Complication in choosing a workplace) of the comedy program 'The East'. This study is conducted by using a descriptive-qualitative approach, aimed to create a description from the perspectives or experiences of the writer. The findings reveal there are totally 26 (twenty-six) violations, each with its implied meaning in the episode of the program. Among the four maxims, the most frequent occurrence is the violation of maxim of Quality with 11 occurrences.
\end{abstract}

Key words: Cooperative Principle, violation of conversational maxims, implicature

\section{INTRODUCTION}

In communicating, there are many purposes or goals the speakers intend to achieve, for example to gain information to earn trusts, to please others, and many others purposes. However, people often unconsciously communicate verbal language that is somewhat different from what they truly mean, or sometimes they can create phrases with certain meaning in their mind. This can cause others to fail to understand the meaning and may result in a misunderstanding between the speaker and the hearer. Misunderstanding can also come from the hearers side, when the hearers infer different meaning from what they hear or from what the speaker trying to implicate. Misunderstanding will cause the speakers to fail to achieve their goals.

To prevent the misunderstanding in making conversation and communicating with others, Grice developed rules of conversation called Cooperative Principle that people can effectively communicate with each other. By following the Cooperative Principle, a successful conversation can be achieved. Cooperative principle consists of four maxims; maxims of quantity, quality, relation and manner (Grice, 1975). All of these maxims should be considered when making a conversation. If it is not applied it will be called as the violation that may create another new meaning to the literal meaning which is called implicature or implied meaning.

One of the situations where people violate the maxims is in a comedy. As we can see nowadays there have been many TV stations having a comedy show as their program. These shows use the setting of our everyday lives that the audience can relate to. The audience loves this kind of show because they can relate to the situation as well as gain humor from it to refresh their mind. We can find violation of cooperative principle as one of the instruments that is needed to create humor in a comedy show (Yuliana, 2007). In addition to the cooperative maxims, Grice developed an influential theory to explain conversational implicatures, and describe how they arise and are understood. Grice was the first to systematically study cases in which what a speaker means differs from what the utterance used by the speaker means. 
This study is focused on the violation of maxims occurring in the humorous utterances in comedy program entitled 'The East' to identify its type and the implicature that can be inferred from the violated maxim. This study is conducted in order to reveal the violation of maxim and the implicature of the violation in NET comedy program 'The East' from discourse analysis point of view. This study is meant to give better understanding of the types of maxims violated in the humorous utterances and the implicatures which can be inferred from the violated maxim.

\section{METHOD}

This study was conducted by using descriptive-qualitative approach. The writer used the descriptive approach since this study dealt with the utterances spoken by the actors and actresses in comedy program 'The East'. It means this study was done by identifying and categorizing the violation of the conversational maxims and the implicature in the utterances producing humor in TV comedy 'The East'. This Qualitative-descriptive approach aimed to create a description from the perspectives or experiences of the writer.

The source of the data was episode 397 entitled 'Ribet Milih Tempat Kerja Baru' (Complication in choosing a workplace) of 'The East' from NET. The writer made transcription from the episode found on Zulu.id. The data were the utterances producing humor signaled by the audience laughter that can be heard during the show. The numbering of the data followed the system of three digit-numbering: the first digit refers to the scene, the second digit refers to the speaker, and the third digit refers to the unit of analysis. The instrument in this study was the writer herself since she was the one who conducted the research, starting from collecting the data analyzing them, and making sense of the analysis.

After transcribing the episode, the writer began her analysis by using the following steps: Analyzing each humorous utterance / unit of utterances to identify the violated maxim; categorizing types of violated maxims; inferring the implied meaning of the violated maxim with some explanation; summarizing the types of violated maxims of the utterances containing laughter to be presented in a table.

\section{FINDINGS AND DISCUSSION}

The findings revealed the violated maxims, the types and the implicature found in the humorous utterances in episode 397 entitled 'Ribet Milih Tempat Kerja Baru' (Complication in choosing a workplace) of the comedy program 'The East'

\section{The Violation of the Maxims and the Implicatures}

The table below shows the number of violation of maxims in the humorous utterances that trigger audience laughter found in the episode.

Table 4.1 The Types of Violated Maxims

\begin{tabular}{|l|l|l|l|}
\hline \multicolumn{2}{|c|}{ Cooperative Principle Maxims } \\
\hline Manner & Relation & Quality & Quantity \\
\hline 4 & 4 & 11 & 7 \\
\hline $\mathbf{2 6}$ & & \\
\hline
\end{tabular}

As presented in the table, there are 26 violations of maxims from the data. Among the four maxims, the one with the most occurrence is the violation of maxim of Quality with 11 
Kencana : Violation of the Conversational Maxims in the Comedy Program 'The East'

occurrences, the second is violation of maxim of Quantity with seven occurrences, and the violation of maxim of Manner and maxim of Relation with the same number, four occurrences.

\section{Violation of Maxim of Quality and the Implicature}

Among the four maxims, the one with most occurrence is the violation of maxim of Quality, which means mostly, the occurrence of humor from the utterances happens when the characters are saying something that is believed as false or lie, or making statements without any supporting evidence which is self-proclaimed remarks. From the data, the writer found out that the characters, especially Doni, are often making self-proclaimed statements without any supporting evidence presented. There are seven humorous utterances that violate the maxim of Quality because they lack adequate evidence. The writer uses conversation from Scene 5 where there are three violations of maxim of Quality in this one scene to explain further about the implicature of the maxim.

\section{SCENE 5}

Context : Doni (D) is sitting in the driver seat, while Fajar (F) and Tomo (T) are in the passenger seat at the back. Doni is in the middle of driving and wants to check for available routes to their destination using his phone.

[5.3.1] D : Waduh mas, kayaknya handphone saya ngehang dah (Oops, bro, I think my cellphone is not working).

F : Masa jatuh begitu doang langsung ngehang. (Really? just a fall like that and then suddenly stop working?)

D : Ya kan handphone saya juga udah uzur mas, udah tua banget ini. (My cellphone is old already bro, it's really old.)

$\mathrm{T}$ : Terus ga bisa cari rute dong mas? (So you can't find the route bro?)

[5.3.2] D : Ya udah mas tenang aja, untung ketemunya sama driver professional. Jakarta mah saya udah hafal semua (Just calm down, luckily you have met a professional driver. Jakarta, I have memorized everything).

$\mathrm{T}$ : Wes kalo misalkan mas Doni tau jalannya. (It's good then if bro Doni knows the way.)

[5.1.1] F : Eh eh loh loh, lo ngapain ke kiri, mending kanan aja. Kiri macet (Eh eh, why are you going to the left, right is better, left is jammed).

The violations of maxim of Quality are in the utterances [5.3.1], [5.3.2], and [5.1.1]. Here in the first utterance with violation [5.3.1] this is actually a lie because in the later scene, Doni is playing a game using the same phone without any problem. Logically, the distance between the seat and the car floor is not that far, and cars usually have some kind of rubber or carpet on its floor. It is strange that his phone is broken just because of that fall. Doni is lying, and it implies that he does not need to use his mobile data to look for routes. In later scene, he mentions that the game he is playing is an offline game. It can be inferred that Doni is a cheapskate who does not want to spend to pay for mobile data, because he is just a temporary driver for that day so the extra cost of using mobile data will not be covered by the Customers, Fajar and Tomo.

Another utterance with violation [5.3.2] is also done by Doni (D) in the same scene; there is no proof that he is a professional driver. Moreover, the earlier scene shows that he forgot to lower the handbrake and even got the Ferrari name wrong as Fareri. Later on Doni, Fajar, and Tomo cannot reach their destination on time because they are stuck in a traffic jam and also because Doni does not know the fastest route to reach their destination. So Doni's selfproclaimed statement that he is a professional driver who has memorized everything about Jakarta violates the maxim of quality. It implies that Doni wanted to reassure Tomo and Fajar so that they will not worry about getting lost in Jakarta. 
The third utterance containing violation [5.1.1] is by Fajar (F). Fajar actually has no source of information and evidence that the left path is jammed. It is pure instinct. He insists to go through the right path and later on they get stuck in a traffic jam. This proves that Fajar's statement violates the maxim of quality. Fajar seems to doubt Doni's ability and professionality. The utterance implies that Fajar is confident and thinks he knows better than Doni.

The violated maxim is related to trustworthiness and integrity which is very important in real communication in daily lives. The humorous utterances manage to catch the audience's attention because the audiences can relate themselves with the situation the characters are in.

\section{Violation of Maxim of Quantity and the Implicature}

The second most violated maxim from the data is maxim of Quantity with seven violations, which means the audiences find the utterances funny because the characters are saying too much or too less than is required. According to the data, all the humorous utterances that violate the maxim of Quantity are because the characters are saying too much more than necessary. The writer uses conversation from Scene 6 where there are two continuous violations of maxim of Quantity in this one scene.

\section{SCENE 6}

Context : Vira (V) just finish setting up her new desk when Iren (I) wants to try Vira's new seat. Iren asks Vira to let her try sitting there, then Iren wants that seat and even makes Vira clear the desk and move away to another desk. But again, Iren changes his mind right after Vira moves.

[6.7.1] I : Eh tapi bentar deh. Ini kalo menurut fengshui ya, Iren tuh ga boleh duduk yang ngadep sekat gitu. Jadi Iren ga boleh duduk yang membelakangi atau menghadap sekat (Uh, but wait, if according to Feng Shui, Iren can't sit with a partition, so Iren can't sit with her back or face the divider).

$\mathrm{V}$ : Gimana sih mba Iren. (What the hell sis Iren.)

[Iren still continuous from her previous explanation]

[6.7.2] I : Iya soalnya kalo ada sekat tuh, apalagi di depan, itu nanti bisa bikin apa ya, bikin ide Iren tuh ga, ga berkembang gitu. Ga, ga berpikiran luas Iren jadinya gitu. Jadi, jadi takutnya jadi stuck gitu kalo nyari ide. Kayaknya Iren ga jadi disini deh. Kayak sumpek gitu ngeliat ke depan. Iren balikin ini kursinya (Because if there is a partition, especially in front, it can make Iren's idea doesn't develop, like that. Can't think broadly, like that. So, Iren afraid to be stuck when looking for ideas. Iren doesn't think Iren will be here. Feels like stuffy when looks forward. Here, Iren return this chair).

Both the first [6.7.1] and second [6.7.2] unit of utterances containing violation of maxim of Quantity in this scene are done by Iren (I). In [6.7.1] Iren realizes that there is partition in front of her new chosen desk. Iren seems to believe in Feng Shui and is afraid that the partition is bad for her. According to feng shui as Iren said, the partition will block her ideas from flowing. She is a creative crew so it will be a problem if her ideas do not flow properly. So she is trying to explain even further to Vira so that Vira will not be angry by her action and will not think that she is doing it on purpose to torture Vira. However, Vira does not seem to care about the feng shui that Iren is trying to explain so Iren is giving too much information about it. From [6.7.2] Iren is panicking and trying her best to explain herself further because Vira starts to show signs of annoyance by Iren's action. She tries to explain even more about her reason and the feng shui, but it is too much of unnecessary information that Vira does not need. Iren is trying to reason herself and violates the maxim to convince Vira so that Vira does not get angry at her. Iren's utterances imply that she really believes in fengshui and does not mean any ill intention or harm to Vira.

The violated maxim of Quantity is because the speaker is being too informative and giving too much more than required. This relates closely to daily conversation and the audiences 
Kencana : Violation of the Conversational Maxims in the Comedy Program 'The East'

can relate themselves with the situation the characters are in, especially when someone is talking too much and people just agree with them so that they will stop talking, just like Vira who just listens to Iren quietly.

\section{Violation of Maxim of Manner and the Implicature}

The data show that there are four violations of maxim of manner in the humorous utterance in episode 397 of comedy show 'The East'. This maxim is focusing on how the speaker conveys the message. The violation of maxim of Manner occurs because the characters are talking in unclear and ambiguous ways.

\section{SCENE 8}

Context : Vira (V) and Iren (I) just finished moving and setting up their new office desk when Gista came. Iren has decided on her new desk which is right across her superior, Gista's desk.

G : Sama dong berarti, gue bisa tau lo lagi kerja apa ga. Kan kita hadap-hadapan. (It means the same, I can tell whether you are working or not. We're face to face)

[8.7.2] I : Iya ya mba, langsung ya mba. Iya ya mba... Vir...(Oh right sis, immediately ya sis. Right sis... Vir...)

The utterances in bold italics are the humorous utterances where violation of maxim of Manner is found. The speaker, Iren (I) at first is proud of her new desk but then she realizes that Gista $(\mathrm{G})$, her superior can observe whether she is working properly or not right away with that desk position. So in her utterances, Iren implies that she wants to swap seats with Vira (V) by calling Vira. Iren cannot say and express herself directly because Gista is with them in the office. So Iren is being ambiguous so Gista does not find out that she does not want to sit across Gista's desk.

The violated maxim of Manner is because the speaker is being unclear and ambiguous. The utterance implied that Iren is afraid of the strict and fierce Gista, her superior. Iren who often slacking during work is always scolds by Gista.

\section{Violation of Maxim of Relation and the Implicature}

From the table, it shows that there are four violations of maxim of Relation from the total of 26 violations. The violation of the maxim of Relation is because the characters of the show speak irrelevantly to the topic or prior conversation.

\section{SCENE 9}

Context : Doni (D), Fajar (F) and Tomo (T) are discussing about the shaking car when suddenly Tomo brings up his stomach ache that suddenly getting worse.

F : Nih mobil kenapa kayak oleng-oleng gini sih? Ada masalah ya sama mobilnya?

D : Ng, nggak koq. AC-nya dingin. Spionnya juga bener. Lampu nyala. Bensin full. Kaca juga kuat.

[9.2.1] T : Eh eh loh loh. Mas Fajar iki kenapa ya koq makin oleng mas. Aduh, aduh mana makin mules lagi. (Ouch, ouch, it gets even more painful.)

In this scene, the violation of maxim of Relation occurs when the speaker, Tomo (T), responding and participating in the conversation brings up his stomach pain that is getting worse. However, he has already felt that stomach ache before the car start shaking, and it has nothing to do with the shaking car, which is the current problem. However his speech is unrelated to the conversation where Fajar and Doni are discussing about the shaking car, thus Tomo violates the maxim of Relation. 
The violated maxim of Relation here is because Tomo, the speaker is trying to express his pain by saying it out loud in the middle of having conversation about another topic, which is the shaking car. It is implied they need to stop and find the cause of the shaking car as fast as possible before Tomo stomach pain goes out of control.

\section{CONCLUSION}

Applying Grice's Cooperative Principle with the four Maxims, this study analyzes the types of maxims that are violated in the utterances that produce humor in the comedy program 'The East' and also the Implicatures of the violation of the maxims.

The findings reveal that the violation of the Cooperative Principle maxims occurs in the humorous utterances in the comedy program 'The East'. Totally, there are 26 (twenty-six) violations in the chosen episode of the program. The one with the most occurance is the violation of maxim of Quality with 11 occurrences, the second is violation of maxim of Quantity with seven occurrences, and the violation of maxim of Manner and maxim of Relation with the same number of occurrences, four. It is also found out that some implied meaning can be inferred from the violated maxims. The implicatures show how the speaker feels about the other character / participant or the situation.

Hopefully, this study has given some insight on the occurance of violations of conversational maxims found in the humorous utterances in the episode of the comedy program 'The East' and the implied meaning which can be inferred. Future studies can be focused on the types of implicatures of violated maxims in other humorous contexts.

\section{REFERENCES}

Attardo, S. (1994). Linguistic Theories of Humor. Berlin: Mouton de Gruyter.

Budianto, L. (2007). The Conversational implicatures in two episodes of Desperate Housewives. Universitas Kristen Petra.

Davis \& Wayne, "Implicature", The Stanford Encyclopedia of Philosophy (Fall 2019 Edition), Edward N. Zalta (ed.), https://plato.stanford.edu/archives/fall2019/entries/implicature/

Hidayati, F., \& Indarti, Y. (2013). An Analysis of the Violation of Maxims In Malam Minggu Miko Situation Comedy. Anglicist, 02.

Sari, P., \& Litbagay, A. (2019). Implicature in the Dialogue of 500 Days of Summer Movie by Marc Webb: The Study of Pragmatics.

Thomas, J. (1995). Meaning in Interaction: An introduction to pragmatics. New York: Longman.

Yuliana. (2007). Humor as a result of the violation of the cooperative principles in "din brodin" Jtv's comedy. Universitas Kristen Petra. 